\title{
Detection of genetically modified plant products by protein strip testing: an evaluation of real-life samples
}

\author{
Marc Van den Bulcke • Adinda De Schrijver • \\ Daniele De Bernardi • Yann Devos • \\ Guillaume MbongoMbella • Amaya Leunda Casi • \\ William Moens $\cdot$ Myriam Sneyers
}

Received: 8 May 2006 / Accepted: 19 May 2006 / Published online: 30 June 2006

(C) Springer-Verlag 2006

\begin{abstract}
The determination of the presence of genetically modified plant material by the detection of expressed genetically engineered proteins using lateral flow protein strip tests has been evaluated in different matrices. The presence of five major genetically engineered proteins (CP4-EPSPS, CryIAb, Cry9C, PAT/pat and PAT/bar protein) was detected at low levels in seeds, seed/leaf powder and leaf tissue from genetically modified soy, maize or oilseed rape. A comparison between "protein strip test" (PST) and "polymerase chain reaction" (PCR) analysis of genetically modified food/feed samples demonstrates complementarities of both techniques.
\end{abstract}

Keywords GMO - Lateral flow $\cdot$ Recombinant proteins · Detection $\cdot$ Food/feed

\section{Introduction}

Genetically modified (GM) crops have become part of the global food/feed market [1]. In many countries, labelling conditions for products that contain traces of GM material have been established. A tolerance threshold of $0.9 \%$ applies for the unintentional or technically unavoidable presence of authorised GM material and in non-GM food and feed in the European Union. Detection, identification and quantification of the presence of GM material along the supply chains are essential to enforce downstream labelling and traceability requirements [2-4].

M. Van den Bulcke $(\varangle) \cdot$ A. De Schrijver · D. De Bernardi · Y. Devos · G. MbongoMbella - A. L. Casi - W. Moens · M. Sneyers Division of Biosafety and Biotechnology, Institute of Public Health,

J. Wytsmanstraat 12-14,

1050 Brussels, Belgium

e-mail: mabul@sbb.ihe.be

e-mail: gmolab@sbb.ihe.be
The amplification and detection of a specific target DNA sequence by the "polymerase chain reaction" (PCR), represents the key technology in the detection protocols of genetically modified organisms (GMO) (for a current review see [5]). Although very sensitive and possibly quantitative, these DNA-based methods require sophisticated laboratory tools, are expensive, time-consuming, and their general robustness is still under evaluation $[6,7]$.

Here the use of a set of commercially available proteinbased tests to detect GM material in real-life samples has been tested (for a method overview see [8]). We designated the test as "protein strip test" (PST). PSTs are simple, cheap, fast and do not require any laboratory facilities or technical expertise. As both PCR and PST have been shown to be valuable tools in detecting GM products, it was considered valuable to compare both techniques and evaluate their complementarity in food/feed GM analysis. The evaluated PSTs cover the detection of the CP4-EPSPS protein [9] (rendering tolerance to the herbicide Glyphosate (Roundup)), the Bacillus thuringiensis (Bt) CryIAb and Cry9C proteins [10] (rendering insect resistance to the European Corn Borer) and $\mathrm{PAT} /$ pat and PAT/bar proteins $[11,12]$ (rendering tolerance to the Glufosinate herbicide (Liberty/BASTA)) as expressed in GM soy, maize and oilseed rape. The complementarities of the PST protein-based detection method and PCR methodology are documented for both food and feed samples.

\section{Materials and methods}

Description of the applied materials

The GM materials applied in this study were obtained from the industry (Aventis/BayerCropScience, Novartis/Syngenta and Monsanto). Certified reference materials 
were purchased from the European Institute for Reference Materials and Methods (IRMM, Be). Comparable control material was obtained from the industry or purchased locally (AVEVE, Be). The food/feed matrices or powders analysed were obtained from the Belgium Federal Agency of Food Safety (FAFS, Be), obtained through the 'GEMMA GM Proficiency Tests' (Central State Laboratory; CSL, UK) or purchased at a local retailer (Delhaize, Be). Seeds were stored at room temperature or at $-20{ }^{\circ} \mathrm{C}$. All other matrices were either stored at $4{ }^{\circ} \mathrm{C}$ (food/feed matrices including powders) or frozen at $-80{ }^{\circ} \mathrm{C}$ (leaf tissue). A comprehensive list of all tested materials is given in Table 1.

\section{PST kits: short methodology description}

PSTs represent a lateral flow detection method, which allows to determine immunologically the presence of the respective genetically engineered (GE) proteins in an extract [8]. All analyses have been performed following the manufacturer procedures, unless otherwise indicated. The following kits have been used: CP4-EPSPS (Neogene, www.neogen.com); CP4-EPSPS, CryIAb, Cry9C, Cry3b, PAT/pat (Envirologix, www.envirologix.com); CP4-EPSPS, PAT/bar (Strategic Diagnostics, www.sdix.com).

\section{GM plant matrix homogenisation and extraction}

Seeds or leaves were grinded using a blender (Kika-Werke Type A10) (about $30 \mathrm{~s}$ at full speed). Homogenised matrix was extracted with tap water $(1-5 \mathrm{w} / \mathrm{v})$. After vortexing (20-30 s), the insoluble material was allowed to settle for 5-10 min. If necessary, the homogenate was cleared by centrifugation at $10,000 \times g$ for $5 \mathrm{~min}$ and analysed by PST.

For single seed kernel analysis, the kernel was incubated in $1 \mathrm{ml}$ tap water for at least $30 \mathrm{~min}$ to allow smoothening of the seed husks. The kernel was then crushed using a plastic stick until the seed content was released (visible by turbidity). The extract was transferred to an eppendorf tube for PST analysis.

Solid matrices from food/feed products were crushed in a Retsch ${ }^{\circledR}$ blender until homogenisation (particle size mesh: $80 \mu \mathrm{m}$ ). Homogenised matrix was extracted by adding between 2 and 10 volumes (w/v) of tap water, depending on the (hygroscopic) nature of the matrix. After vortexing (20 s), $1.5 \mathrm{ml}$ supernatant was cleared by centrifugation for $5 \mathrm{~min}$ at $12,000 \times g$. In case of liquid matrices (e.g. milk, soy sauce), $1 \mathrm{ml}$ of the matrix was diluted five times with tap water, vortexed for $20 \mathrm{~s}$ and tested by PST. In case of the Bt proteins, the extraction of the matrices was also performed by incubating the homogenate for $10-60 \mathrm{~min}$ at room temperature in $0.1-1 \%$ CTAB (10 mM Tris-HCl, $\mathrm{pH}=7.6)$.

\section{PST detection sensitivity determination}

The detection sensitivity has been evaluated at the qualitative level in two different ways. First, $100 \mathrm{mg}$ of seed/leaf powder matrix containing a known weight percentage of the GM material was extracted as described earlier. From the extract, a dilution series ranging from 1:1 to 1:1,000 (or as otherwise indicated) was prepared in tap water and tested by PST (v/v approach). Second, transgenic crushed material was mixed with non-transgenic material at $0,0.1,0.5$ and $1.0 \%$ levels (w/w approach). Extraction and PST analysis were performed as described earlier. All analyses were performed at least in duplicate.

\section{Temperature and protease stability analysis}

The temperature stability of the genetically engineered CP4EPSPS, CryIAb and PAT/pat proteins was tested by incubating $100 \mathrm{mg}$ seed powders from GTS-40-3-2 soy (CP4EPSPS) and Bt11 maize (CryIAb and PAT/pat) for $30 \mathrm{~min}$ at $30^{\circ} \mathrm{C}$ (elevated ambient temperature) and at 55 and $80^{\circ} \mathrm{C}$ (common processing temperatures). Protease sensitivity of the GE proteins was tested by incubating extracts from $100 \mathrm{mg}$ of the respective seed powders for $1 \mathrm{~h}$ at $50{ }^{\circ} \mathrm{C}$ with proteinase $\mathrm{K}$ (Boehringer, Ger) $(1 \mu \mathrm{g} / \mathrm{mg}$ powder). Incubation by released endo-proteases upon leaf tissue extraction was allowed to proceed for $30 \mathrm{~min}$ at room temperature (= maximal exposure time during extraction).

\section{Matrix influences on GE protein detection by PST}

Matrix influences on PST were scored through spiking experiments. One hundred milligrams of seed was mixed with $1 \mathrm{~g}$ or $1 \mathrm{ml}$ homogenised matrix of a number of retailer products (soy sauce, instant soup, ketchup, biscuits, concentrated milk and noodles). The mixtures were extracted with 5 volumes of water. As a reference, $100 \mathrm{mg}$ of the seed powder was extracted with an equal volume of water. Interference with the PST was evaluated by visual comparison between the detected GE protein amount in spiked and reference samples.

\section{Side-to-side PST and PCR analysis of GM plant-derived matrices}

Food/feed samples were analysed for the presence of GM material by PST and PCR (see Table 4). PST analysis was performed as described earlier. All food samples were tested with CP4-EPSPS, CryIAb and PAT/pat PST; the feed samples were tested with CP4-EPSPS PST from Envirologix and Neogene. DNA was extracted from homogenised material using a CTAB extraction kit [13] or commercially available DNA extraction kits (Wizard ${ }^{\circledR}$ Magnetic DNA Purification System for Food from Promega, ChargeSwith gDNA Plant 
Table 1 Description of test substances and analytical samples

\begin{tabular}{|c|c|c|c|c|}
\hline \multicolumn{5}{|c|}{ A: Test substances } \\
\hline & Plant & GM event & Type & Company \\
\hline \multicolumn{5}{|c|}{ A.1 Test substances (provided by the industry) } \\
\hline A.1.1 & Soy & GTS-40-3-2 & Seed & MONSANTO \\
\hline A.1.2 & Maize & Bt176 & Seed & NOVARTIS \\
\hline A.1.3 & Maize & Bt11 & Seed & NOVARTIS \\
\hline A.1.4 & Maize & MON810 & Seed & MONSANTO \\
\hline A.1.5 & Maize & NK603 & Seed & MONSANTO \\
\hline A.1.6 & Maize & GA21 & Seed & MONSANTO \\
\hline A.1.7 & Soy & Control (non-transgenic) & Seed & MONSANTO \\
\hline A. 1.8 & Maize & Control (non-transgenic) & Seed & MONSANTO \\
\hline A.1.9 & Maize & Control (non-transgenic) & Seed & NOVARTIS \\
\hline A.1.10 & Oilseed rape & MS8/RF3 & Leaf powder & AVENTIS \\
\hline \multicolumn{5}{|c|}{ A.2 Certified reference materials (Institute of Reference Materials and Methods (IRMM, Be) } \\
\hline A.2.1 & Soy & GTS-40-3-2 & Seed powder & IRMM \\
\hline A.2.2 & Maize & Bt176 & Seed powder & IRMM \\
\hline A.2.3 & Maize & Bt11 & Seed powder & IRMM \\
\hline A.2.4 & Maize & MON810 & Seed powder & IRMM \\
\hline A.2.5 & Maize & NK603 & Seed powder & IRMM \\
\hline A.2.6 & Soy & Control (non-transgenic) & Seed powder & IRMM \\
\hline A.2.7 & Maize & Control (non-transgenic) & Seed powder & IRMM \\
\hline \multicolumn{5}{|c|}{ B. Analytical samples } \\
\hline & Nature & ISP-ID & Provision date & \\
\hline \multicolumn{5}{|c|}{ B.1 Official samples 2004 (Federal Agency of Food Safety, Be) } \\
\hline B.1.1 & Cattle feed & $\begin{array}{l}0562,0689,0739,0789,0867,0880 \\
1557,1256,0965,1021,0316,0058 \\
0152,0643\end{array}$ & 2004 & \\
\hline B.1.2 & Poultry feed & $\begin{array}{l}0565,0753,0855,0861,1320,1392 \\
1542,0807\end{array}$ & 2004 & \\
\hline B.1.3 & Pork feed & $0690,0746,0809,0808,0888,1414$ & 2004 & \\
\hline B.1.4 & Food (including soy and maize ingredients) & $0439,0440,0441,0663$ & $2003 / 04$ & \\
\hline \multicolumn{5}{|c|}{ B.2 'Proficiency testing' analytical samples (CSL, UK) } \\
\hline B.2.1 & Dry pastry mix (including wheat and soy flour) & 28A 018 & 2004 & \\
\hline B.2.2 & Dry pastry mix (including wheat and soy flour) & 28B 018 & 2004 & \\
\hline B.2.3 & Soy flour & 17 A 077 & 2004 & \\
\hline B.2.4 & Baked biscuit (including soy/wheat flour, full fat milk) & 27020 & 2004 & \\
\hline B.2.5 & Soy/wheat flour & 2011 & 2004 & \\
\hline B.2.6 & Snack food crumb & 21051 & 2004 & \\
\hline B.2.7 & Bread powder (including wheat and soy flour) & 12049 & 2004 & \\
\hline B.2.8 & Soy/maize flour & 14 A 104 & 2004 & \\
\hline B.2.9 & Soy flour & 26 B 043 & 2004 & \\
\hline B.2.10 & Soy/wheat flour & 16 А 024 & 2004 & \\
\hline \multicolumn{5}{|c|}{ B.3 Local retailer products 2004/5 (AVEVE, Be; Delhaize, Be) } \\
\hline B.3.1 & Maize seeds Anjou 249 (AVEVE) & ISP-Zm01 & 2004 & \\
\hline B.3.2 & Oilseed rape seeds Stego (AVEVE) & ISP-Bn01 & 2004 & \\
\hline B.3.3 & Bio soy sauce (Delhaize) & ISP-SF01 & 2004 & \\
\hline B.3.1 & Tomato ketchup (Delhaize) (maize ingredients) & ISP-TF01 & 2004 & \\
\hline B.3.4 & Instant soup (Delhaize) (maize ingredients) & ISP-MF01 & 2004 & \\
\hline B.3.5 & Maize noodles (Delhaize) & ISP-MF02 & 2004 & \\
\hline B.3.6 & Concentrated milk (Delhaize) & ISP-F01 & 2004 & \\
\hline B.3.7 & Biscuits (Delhaize) (soy, maize ingredients) & ISP-MS01 & 2004 & \\
\hline
\end{tabular}

ISP-ID, Institute of Public Health Identification. 
Table 2 Detectable GE protein levels in different plant GMO matrices by PST: the dilution approach (v/v)

\begin{tabular}{|c|c|c|c|c|c|}
\hline \multirow[b]{2}{*}{ Crop matrix event } & \multicolumn{5}{|l|}{ Trait } \\
\hline & CP4-EPSPS & CryIAb & Cry9C & $\mathrm{PAT} / p a t$ & $\mathrm{PAT} /$ bar \\
\hline IRMM $1 \%$ soy GTS-40-3-2 & $1: 10,000$ & na & na & na & na \\
\hline IRMM $2 \%$ maize $\mathrm{Bt} 176$ & na & nd & na & na & nd \\
\hline IRMM 5\% maize Bt11 & na & nd & na & nd & na \\
\hline IRMM 2\% maize MON810 & na & nd & na & na & na \\
\hline IRMM 5\% maize NK603 & $1: 1,000$ & na & na & na & na \\
\hline Seed soy GTS-40-3-2 & $\begin{array}{l}1: 10,000 \\
0.25(0.035)\end{array}$ & na & na & na & na \\
\hline Seed maize Bt176 & na & $\begin{array}{l}\text { nd } \\
\text { nd }\end{array}$ & na & na & $\begin{array}{l}\text { nd } \\
\text { nd }\end{array}$ \\
\hline Seed maize Bt11 & na & $\begin{array}{l}1: 200 \\
10.9(2.6)\end{array}$ & na & $\begin{array}{l}\text { nd } \\
0.04(0.01)\end{array}$ & na \\
\hline Seed maize CBH351 & na & na & $\begin{array}{l}1: 1,000 \\
0.04(0.01)\end{array}$ & na & $\begin{array}{l}1: 5,000 \\
\mathrm{ni}\end{array}$ \\
\hline Seed maize MON810 & na & $\begin{array}{l}\text { nd } \\
\text { nd }\end{array}$ & na & na & na \\
\hline Seed maize NK603 & $\begin{array}{l}1: 1,000 \\
10.9(2.6)\end{array}$ & na & na & na & na \\
\hline Seed maize GA21 & $\begin{array}{l}\text { nd } \\
\text { na }\end{array}$ & na & na & na & na \\
\hline Leaf soy GTS-40-3-2 & $\begin{array}{l}1: 100 \\
0.45(0.1)\end{array}$ & na & na & na & na \\
\hline Leaf maize Bt176 & na & $\begin{array}{l}1: 100 \\
7.6(0.3)\end{array}$ & na & na & $\begin{array}{l}\text { nt } \\
\text { nd }\end{array}$ \\
\hline Leaf maize Bt11 & na & $\begin{array}{l}1: 100 \\
5.0(0.7)\end{array}$ & na & $\begin{array}{l}1: 2 \\
1.5(0.7)\end{array}$ & na \\
\hline Leaf maize CBH351 & na & na & $\begin{array}{l}1: 1,000 \\
\text { ni }\end{array}$ & na & $\begin{array}{l}1: 10,000 \\
\mathrm{ni}\end{array}$ \\
\hline Leaf maize MON810 & na & $\begin{array}{l}1: 100 \\
11.8(1.4)\end{array}$ & na & na & na \\
\hline Leaf oilseed rape MS8/RF3 & na & na & na & na & $\begin{array}{l}1: 5,000 \\
1.5(0.15)^{\mathrm{a}}\end{array}$ \\
\hline
\end{tabular}

nd, not detectable; na, not applicable; ni, not indicated.

${ }^{a} \mathrm{GE}$ protein content (micrograms per milligrams of fresh weight or milligrams of protein).

Kit from Invitrogen, GeneSpin Extraction Kit from GeneScan). The extraction was performed according to the manufacturer's recommendations. The extracted DNA concentration was determined spectrophotometrically (UV 260/280) or fluorimetrically (Picogreen).

For the detection of elements derived from the CP4EPSPS [9], the 35S cauliflower mosaic virus promoter [14] and the Agrobacterium tumefasciens NOS terminator [15], generic primers were used applying standard amplification and electrophoresis protocols (G. Berben, personal communication) [16]. Generic plant primers and crop specific primers for soy (lectin) and maize (zein) markers were included in the analysis [17, 18]. Quantitative analyses were performed using event-specific Taqman primers/probe system within a real-time PCR DNA amplification set-up (ABIPrism 7700 system). Tested event-specific methods comprised the Roundup Ready (RR) soy event GTS-40-3-2, and the Bacillus thuringiensis (Bt) maize events Bt176, Bt11 and MON810 [19].

\section{Results and discussion}

Sensitivity of the detection of GE proteins by PST

PSTs are protein-based tests allowing the detection of GM events in matrices that contain the GE proteins in a watersoluble form at a sufficiently high concentration. In Table 2, the concentration of the GE proteins present in seeds and leaves of the analysed GM events is indicated. Reported data were obtained from official registration dossiers.

Single kernel analysis (three kernels analysed per event) or seed powder analysis (produced from 30 test seeds or obtained from the IRMM (100 mg)), gave positive results with the expected PST in all cases (in case of CP4-EPSPS (GTS40-3-2 soy and NK603 maize); CryIAb (Bt11 maize); Cry9C (CBH351 maize); PAT/pat (Bt11 maize); PAT/bar (CBH351 maize and MS8/RF3 oilseed rape)). Bt176 and MON810 maize seed powders and any tested GA21 maize matrix were negative. In seeds of the first two $\mathrm{Bt}$ maize events, the 

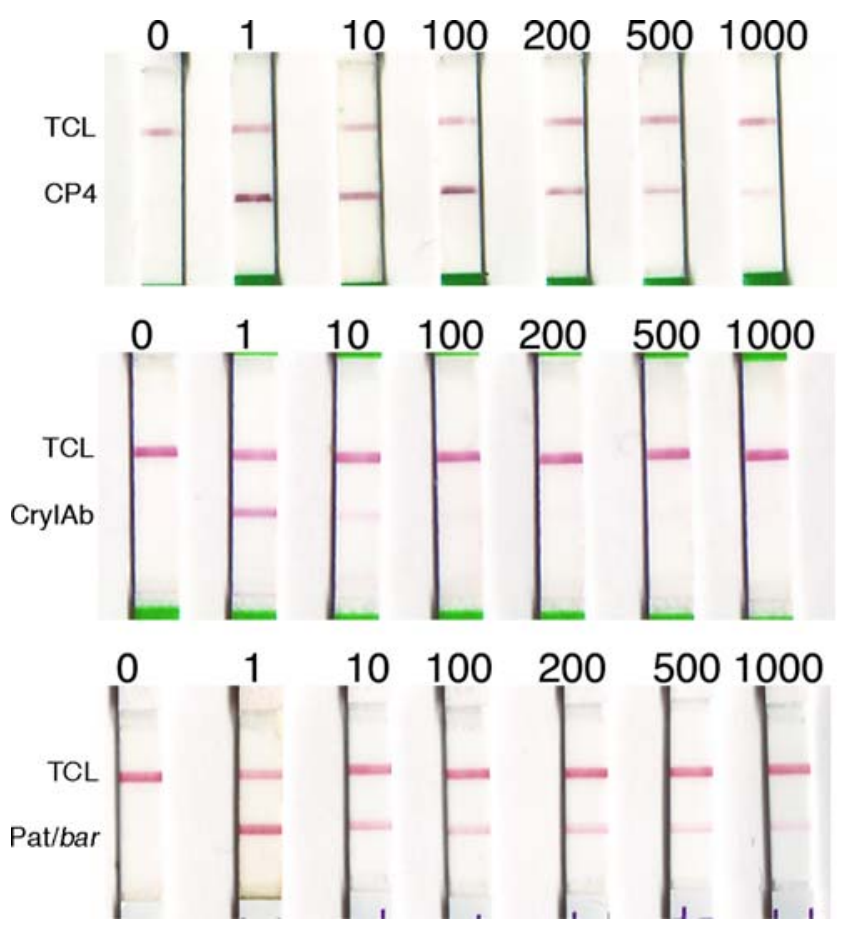

Fig. 1 PST analysis by v/v dilution of GM powder of GTS-40-3-2 soy (EPSPS-CP4 PST (Neogene); top panel), Bt11 maize (CryIAb PST (Envirologix); middle panel) and MS8/RF3 oilseed rape (PAT/bar PST (SDI); bottom panel). The dilution level is indicated on top of each strip. ' 0 ' represents non-transgenic control powder from soy (top), maize (middle) and oilseed rape (bottom). 'TLC' stands for 'test control line'

concentration of the GE proteins is probably too low to be detected immunologically (see Table 2 ). The GA21 maize contains a mutated plant EPSPS protein, which is not recognised by any of the provided CP4-EPSPS PSTs, as documented by the PST providers (see PST documentation sheets of Neogene, Envirologix or SDI). All tested non-transgenic single seed or plant controls were negative for all PSTs.

The sensitivity of the respective PSTs was determined for (i) powders derived from seeds or leaves, (ii) certified reference materials from the IRMM and (iii) fresh leaf tissue from GM plants. Dilution profiles (v/v) of $100 \mathrm{mg}$ crushed powder from 100\% GTS-40-3-2 soy seeds (CP4-EPSPS PST Neogene), from $100 \%$ Bt11 maize seeds (CryIAb PST Envirologix) and from 100\% MS8/RF3 oilseed rape leaves (PAT/bar PST SDI) are shown in Fig. 1. Up to a 100-fold dilution, the positive signal remains constant (substrate saturation level). Then the signal gradually declines and disappears below a $200,1,000$ or 5,000 -fold dilution in case of Bt11 maize, GTS-40-3-2 soy and MS8/RF3 oilseed rape, respectively. A similar analysis was performed for all GM events. The maximal dilution ratio where detection by PST gave clear positive results is listed in Table 2.

The detection sensitivity of the PST is high $(>1: 1,000)$ for the CP4-EPSPS protein (seeds/leaves from GTS-40-3-2 soy and seeds from NK603 maize) (Neogene $>$ Envirogix/SDI), the Cry9C protein (seeds/leaves from $\mathrm{CBH} 351$ maize) and the PAT/bar protein (seeds/leaves from CBH351 maize and leaves from MS8/RF3 oilseed rape). The PAT/bar protein in Bt176 maize seeds was not detectable. The PAT/pat protein was only detectable at a 1:2 dilution in Bt11 maize leaf tissue but not in seeds. The CryIAb protein was detectable in Bt11 maize seeds (1:200), but not in seeds from Bt176 and MON810 maize. In leaves, the CryIAb protein was detectable at 1:100 in all tested CryIAb maize. Attempts to increase the extraction efficiency by including $\mathrm{CTAB}$, a common surfactant, were unsuccessful. Inclusion of alphaamylase in the buffer (500 units/ml, $15 \mathrm{~min}$ at room temperature) resulted only in a slight increase in the recovery of the CryIAb protein from Bt11 maize seed powder matrix. Comparable analysis of a number of IRMM seed powders gave similar profiles as the PST analysis of the powders produced from the seeds provided by the companies, except for the maize Bt11 event where no GE CryIAb was detected in the IRMM powder.

A number of $1,0.5$ and $0.1 \% \mathrm{GM} / \mathrm{non}-\mathrm{GM}(\mathrm{w} / \mathrm{w})$ mixtures were analysed by PST. The lowest percentage detectable GM material in the seed powder $(\mathrm{S})$ or leaf tissue $(\mathrm{L})$ mixtures were $0.1 \%$ (S), $1.0 \%$ (L) for GTS-40-3-2 soy; $0.5 \%$ (S), $1.0 \%$ (L) for Bt11 maize; $0.1 \%(\mathrm{~S}), 0.1 \%(\mathrm{~L})$ for $\mathrm{CBH} 351$ maize and $0.1 \%$ (L) for MS8/RF3 oilseed rape. The values obtained in the w/w analysis are in line with the results obtained with the $\mathrm{v} / \mathrm{v}$ dilution approach.

All the above results confirm claims formulated by the respective PST producers and broaden the scope of application of PSTs to a wider range of matrices [20]. In all further analysis, we have focussed on the use of PSTs detecting the three major GE traits currently in the market, CP4-EPSPS, CryIAb and PAT/pat. Using these PSTs, the presence of the following GM events can be traced: GTS-40-3-2 soy and NK603 maize (CP4-EPSPS); Bt176, Bt11, MON810 maize (CryIAb), Bt11 maize (PAT/pat). Note that the above combination of PSTs would allow to test for the presence of several other GM events, which could not be evaluated in this study due to the lack of (reference) material (for additional information reference is made to the product documentation provided by the PST producers).

Influence of physico-chemical properties of the GE proteins on PST

All tested GE proteins are from bacterial origin (except the mutated plant EPSPS protein present in GA21 maize). As the amino acid homology analysis demonstrated the absence of any homology of the GE proteins with other plant proteins (data in registration files), no cross-reactivity with plant proteins is expected. The PSTs showed to be very specific to the GE proteins and no cross-reaction was observed with proteins present in any of the tested control matrices. 
Table 3 Influence of physico-chemical properties of GE CP4-EPSPS, CryIAb and $\mathrm{PAT} /$ pat proteins on PST analysis

na, not applicable; nt, not tested; res., resistant; sens., sensitive.

\begin{tabular}{cllll}
\hline & Nature & CP4-EPSPS & CrylAb & PAT/pat \\
\hline Thermostability & (ambient $/ 55^{\circ}$ C $/ 80{ }^{\circ}$ C) & & \\
A.1.1 & Seed powder soy GTS-40-3-2 & $+/+/-$ & na & na \\
A.1.3 & Seed powder maize Bt11 & na & $+/+/-$ & $+/+/-$ \\
A.1.1 & Leaf soy GTS-40-3-2 & $+/ \mathrm{nt} / \mathrm{nt}$ & na & na \\
A.1.3 & Leaf maize B11 & na & $+/ \mathrm{nt} / \mathrm{nt}$ & $-/ \mathrm{nt} / \mathrm{nt}$ \\
Protease sensitivity (proteinase K (PK), leaf proteases (LP)) & & & \\
A.1.1 & Seed powder soy GTS-40-3-2 & PK sens & na & na \\
A.1.3 & Seed powder maize Bt11 & na & PK sens & PK sens \\
A.1.1 & Leaf soy GTS-40-3-2 & LP res & na & na \\
A.1.3 & Leaf maize Bt11 & na & LP res & LP sens \\
Matrix quenching influence: spiking recovery analysis (soy GTS40-3-2 & maize Bt11 seed powder) \\
Spike & Seed powder (GTS-40-3-2 soy / Bt11 maize) $)$ & +++ & +++ & + \\
B.3.3 & Bio soy sauce & +++ & + & - \\
B.3.1 & Tomato ketchup & +++ & +++ & - \\
B.3.4 & Instant soup & +++ & +++ & - \\
B.3.5 & Noodles & + & + & - \\
B.3.6 & Concentrated milk & +++ & - & - \\
B.3.7 & Biscuits & +++ & +++ & - \\
0100 & Feed (cattle) & +++ & - & - \\
0192 & Feed (poultry) & +++ & ++ & - \\
0281 & Feed (pork) & +++ & ++ & - \\
\hline
\end{tabular}

In addition to the concentration of the GE protein, also the physico-chemical properties of the GE proteins will influence the utility of the PST as a tool to detect GM traces in complex matrices. Three parameters that influence in general immuno-assays were tested for PST: thermostability, protease sensitivity of the GE proteins and matrix quenching effects. The results of the analysis are summarised in Table 3.

The thermostability of the GE CP4-EPSPS, CryIAb and $\mathrm{PAT} /$ pat proteins after extraction was tested at ambient temperature and at elevated temperatures. The GE proteins were stable in extracts from seed powders for at least $30 \mathrm{~min}$ at room temperature. In leaf extracts, the CP4-EPSPS and the CryIAb protein were stable for at least $30 \mathrm{~min}$ but the PAT/pat protein was not detectable after $5 \mathrm{~min}$ (see also below). At $55^{\circ} \mathrm{C}$, the CP4-EPSPS and the CryIAb protein could still be detected; the PAT/pat protein, however, disappeared completely. None of the tested GE proteins was detectable after incubating seed powders for $1 \mathrm{~h}$ at $80^{\circ} \mathrm{C}$.

Upon proteinase $\mathrm{K}$ treatment of seed powder extracts, the CP4-EPSPS, the CryIAb and the PAT/pat protein completely disappeared. Incubation at room temperature of the GE proteins in leaf protein extracts showed that the GE CP4-EPSPS and CryIAb proteins are resistant to 30 min exposure to leaf proteases. The GE PAT/pat protein was, however, degraded within less than $5 \mathrm{~min}$. Performing the extraction at $4{ }^{\circ} \mathrm{C}$, protected the GE PAT/pat protein from leaf protease degradation for at least $30 \mathrm{~min}$.

The extraction from complex matrices can release a broad variety of compounds that can interfere with the immunoreaction of the PST. Based on the product composition label of the retailer products, the following PSTs were performed: (i) soy-containing items were checked for CP4-EPSPS (including soy sauce, instant soup), (ii) maize-containing products for CP4-EPSPS, CryIAb, Cry9C, Cry3b and PAT/pat (including biscuits, ketchup and noodles). In addition, concentrated milk powder was tested for all GE proteins. Three non-GM containing feed-type matrices (representing bovine, chicken and pork feed) were analysed for the presence of GE CP4-EPSPS, CryIAb and PAT/pat protein. None of the retailer matrices tested positive for any of the PSTs. The absence of GM material in the feed receptor matrices was verified by preceding PCR and PST analysis (data not shown). To evaluate any quenching matrix effects on the PST, spiking experiments on purchased food or analysed feed products were performed (see Table 3). In case of the CP4-EPSPS PST, only a noodle pasta extract interfered to some extent with the analysis (similar interference was found with all three CP4-EPSPS PSTs; data not shown). In the case of the CryIAb protein, the outcome of the PST analysis from the spiked samples was variable. Finally, the PAT/pat protein was barely detected in the extracts from spiked samples, presumably due to the unstability of the protein.

These analyses indicate that the GE CP4-EPSPS and the CryIAb proteins sustain proteases well and are relatively resistant to elevated temperature (at least up to $55^{\circ} \mathrm{C}$ ). The GE PAT/pat protein, however, is a very unstable protein. While the GE CP4-EPSPS and the CryIAb proteins can be considered as suitable markers for GM presence in food/feed matrices, which have not been exposed to high temperature processing steps, the GE PAT/pat protein is not suited for GM tracing by PST in these types of matrices. The variability of 
Table 4 Comparison of CP4-EPSPS and PCR analysis of food/feed matrices containing soy and/or maize (for sample references see Table 1)

\begin{tabular}{|c|c|c|c|c|}
\hline Sample & Nature & CP4-EPSPS & $\%$ RR (PCR) & \% Soy (PCR) \\
\hline \multicolumn{5}{|c|}{ GEMMA samples (CSL) } \\
\hline B.2.1 & Soy & $+\mathrm{e}$ & + & +++ \\
\hline B.2.2 & Soy & - & - & +++ \\
\hline B.2.3 & Soy & $+\mathrm{e}$ & ++ & +++ \\
\hline B.2.4 & Soy & $-\mathrm{e},+\mathrm{n}$ & ++ & +++ \\
\hline B.2.5 & Soy & $+\mathrm{e}$ & ++ & ++ \\
\hline B.2.6 & Maize & - & - & nd \\
\hline B.2.7 & Soy & $-\mathrm{e},+\mathrm{n}$ & ++ & + \\
\hline B.2.8 & Soy/maize & - & + & +++ \\
\hline B.2.9 & Soy & - & - & +++ \\
\hline B.2.10 & Soy & - & - & +++ \\
\hline \multicolumn{5}{|c|}{ Food samples (FAFS) } \\
\hline 0439 & Soy & $+\mathrm{e},+\mathrm{n}$ & ++ & + \\
\hline 0440 & Maize & - & nd & nd \\
\hline 0441 & Maize & - & nd & nd \\
\hline 0663 & Maize & - & nd & nd \\
\hline \multicolumn{5}{|c|}{ Feed samples (FAFS) } \\
\hline 0562 & Cattle & $+\mathrm{e},+\mathrm{n}$ & +++ & + \\
\hline 0689 & Cattle & $+\mathrm{e},+\mathrm{n}$ & +++ & + \\
\hline 0739 & Cattle & - & - & + \\
\hline 0789 & Cattle & $-\mathrm{e},+\mathrm{n}$ & ++ & + \\
\hline 0867 & Cattle & - & - & - \\
\hline 0880 & Cattle & $-\mathrm{e},+\mathrm{n}$ & + & + \\
\hline 1554 & Cattle & $+\mathrm{e},-\mathrm{n}$ & + & +++ \\
\hline 1256 & Cattle & $+\mathrm{e},+\mathrm{n}$ & +++ & ++ \\
\hline 0965 & Cattle & $+\mathrm{e},+\mathrm{n}$ & - & - \\
\hline 1021 & Cattle & - & - & - \\
\hline 0316 & Cattle & $+\mathrm{e},+\mathrm{n}$ & +++ & ++ \\
\hline 0754 & Cattle & $+\mathrm{e},+\mathrm{n}$ & ++ & ++ \\
\hline 1321 & Cattle & $-\mathrm{e},+\mathrm{n}$ & + & +++ \\
\hline 0643 & Cattle & $-\mathrm{e},+\mathrm{n}$ & +++ & + \\
\hline 0565 & Poultry & - & ++ & + \\
\hline 0753 & Poultry & - & + & + \\
\hline 0855 & Poultry & $-\mathrm{e},+\mathrm{n}$ & ++ & ++ \\
\hline 0861 & Poultry & - & - & - \\
\hline 1320 & Poultry & - & - & +++ \\
\hline 1392 & Poultry & - & + & ++ \\
\hline 1524 & Poultry & - & + & +++ \\
\hline 0807 & Poultry & $-\mathrm{e},+\mathrm{n}$ & +++ & + \\
\hline 0690 & Pork & - & + & + \\
\hline 0746 & Pork & - & + & + \\
\hline 0801 & Pork & $-\mathrm{e},+\mathrm{n}$ & + & ++ \\
\hline 0808 & Pork & - & - & - \\
\hline 0888 & Pork & - & - & - \\
\hline 1414 & Pork & - & - & +++ \\
\hline
\end{tabular}

matrix quenching effects on the outcome of the PST analysis invokes a 'case-by-case' evaluation in the detection of GM material in food/feed matrices.

\section{GM food/feed analysis: a comparison PST versus PCR}

GM detection results obtained by PST and PCR analysis of the same samples have been compared. Three types of material were analysed: 10 food matrices obtained within the
GEMMA proficiency tests, and 4 food and 30 feed products obtained from the FAFS. The results of these analyses are listed in Table 4.

The CP4-EPSPS PST analyses of the GEMMA samples and the food samples from the FAFS are in line with the results obtained by the RRS PCR analysis. Only CP4-EPSPS could be traced in the different matrices. No traces of CryIAb protein could be detected. The PCR and PST data for the GEMMA samples moreover corresponded 
with the presence/absence of GM soy in the sample, as described in the CSL sample recipe.

A more comprehensive study was made for feed samples present in the market during the year 2004. In total, 30 different feed samples were analysed including 13 cattle-feed samples, 9 poultry-feed samples and 6 pork-feed samples. The quantitative PCR analysis indicated that in general the level of soy material present in most of the feed samples was low $(=\%$ Soy $(\mathrm{PCR}))$. Although the relative amount of RoundupReady soy $(=\%$ RRS $(\mathrm{PCR}))$ present within the soy material was in some cases high, all positive PST signals were weak (at the intensity between 1:1,000 and 1:10,000 $\mathrm{v} / \mathrm{v}$ dilution) (data not shown). These comparative analyses indicated, however, that in most cases the PCR and PST results match in a qualitative way, even when the absolute amount of GM soy in the feed sample is very low. Due to the lack of equivalent quantitative or qualitative scoring parameters (except positive/negative), no statistical analysis has been performed. In several samples, only the Neogene PST gave positive results indicating the very high sensitivity of this assay (see Table 1). In sample ISP-ID 1,554, only the Envirologix PST gave a positive result as the extract itself interfered with the Neogene PST (no positive band for the test control line). In several samples $(0565,0753,1392$, 1524,0690 and 0746 ), no positive PST results were obtained, although the PCR results were positive. In all cases, the absolute level of RRS material in the sample was very low, confirming that at low levels of GM material, PCR remains the more sensitive detection method and the PST can only be used as a positive indication of GM presence in food/feed samples.

\section{Conclusion}

PSTs represent a useful tool to trace all tested GE proteins in raw materials such as seeds and leaves from crop plants. In food/feed products, the PST applicability in GM tracing is restricted to samples containing sufficient GM material derived from plant tissues where the recombinant GE protein is expressed and limited by the inherent physico-chemical properties of the GE proteins themselves (thermostability, quenching interference). Among the evaluated GE proteins, the CP4-EPSPS protein can be considered as the most useful GM marker in food/feed products, the CryIAb protein to a much lesser extent. The PAT/pat protein is not suited to this purpose.

\section{References}

1. James C (2004) Global status of commercialized transgenic crops: 2004. ISAAA Brief, no. 32. Ithaca, New York
2. EC (2001) Directive 2001/18/EC of the European Parliament and of the Council of 12 March 2001 on the deliberate release into the environment of genetically modified organisms and repealing Council Directive 90/220/EEC. Off J Eur Communities L106:139

3. EC (2003a) Regulation (EC) $1829 / 2003$ of the European Parliament and of the Council of 22 September 2003 on genetically modified food and feed. Off J Eur Communities L268:1-23

4. EC (2003b) Regulation (EC) 1830/2003 of the European Parliament and of the Council of 22 September 2003 concerning the traceability and labelling of genetically modified organisms and the traceability of food and feed products produced from genetically modified organisms and amending Directive 2001/18/EC Off J Eur Communities L268:24-28

5. Holst-Jensen AH, Berdal KG (2004) The modular analytical procedure and validation approach and the units of measurement for genetically modified materials in foods and feeds. J AOAC Int 87:927-936

6. Anklam E, Heinze P, Kay S, Van den Eede G (2002) Validation studies and proficiency testing. J AOAC Int 85(3):809-815

7. Bertheau Y, Diolez A, Kobilinsky A, Magin K (2002) Detection methods and performance criteria for genetically modified organisms. J AOAC Int 85(3):801-808

8. Stave J (2002) Protein immunoassays methods for detection of biotech crops: applications, limitations and practical considerations. J AOAC Int 85(3):780-786

9. Barry G, Kishore G, Padgette S, Taylor M, Kolacz K, Weldon M, Re D, Eichholtz D, Fincher K, Hallas L (1992) Inhibitors of amino acid biosynthesis: strategies for imparting glyphosate tolerance to crop plants. In: Singh et al. (eds) Biosynthesis and molecular regulation of amino acids in plants. American Society of Plant Physiologists, pp 139-145

10. Koziel MG, Carozzi NB, Currier TC, Warren GW, Evola S (1993) The insecticidal crystal proteins of bacillus thuringiensis: past, present and future uses. In: Tombs MP (ed) Biotechnology and genetic engeneering reviews, vol. 11. Intercept, Andover, UK, pp $171-228$

11. Wohlleben W, Arnold W, Broer I, Hillemann D, Strauch E, Pühler A (1988) Nucleotide sequence of the phosphinotricine $\mathrm{N}$-acetyltransferase gene from Streptomyces viridochromogenes Tü494 and its expression in Nicotiana tabacum. Gene 70:25-37

12. De Block M, Botterman J, Vandewiele M, Dockx J, Thoen C, Gosselé V, Movva NR, Thompson C, Van Montagu M, Leemans J (1987) Engineering herbicide resistance in plants by expression of a detoxifying enzyme. EMBO J 6:2513-2518

13. Hüpfer C, Hotzel H, Sachse K, Engel KH (1998) Detection of the genetic modification in heat-treated products by BT-maize polymerase chain reaction. Zeitschrift für Lebensmittel-Untersuchnung und -Forschung A206:203-207

14. Odell JT, Nagy F, Chua NH (1985) Identification of DNA sequences required for the activity of the cauliflower mosaic virus 35S promoter. Nature 313:810-812

15. Depicker A, Stachel S, Dhaese P, Seurinck J, Deboeck F, De Greve H, Lemmers M, Van Montagu M, Schell J (1982) Nopaline synthase: transcript mapping and DNA sequence. J Mol Appl Genet $1: 1-573$

16. Lipp M, Bluth A, Euquem F, Kruse L, Schimmel H, Van den Eede G, Anklam E (2001) Validation of a method based on polymerase chain reaction for the detection of genetically modified organisms in various processed foodstuffs. Eur Food Res Technol 212:497504

17. Pietsch K, Waiblinger HU, Brodmann P, Wurz A (1997) Screeningverfahren zur Identifizierung "genetisch veränderter" pflanzlicher Lebensmittel. Deutsche Lebensmittel-Rundschau 93(2):35-38 
18. Studer E, Dahinden I, Lüthy J, Hübner P (1997) Nachweis des genetisch veränderten "Maximizer"-Mais mittels der polymeraseKettenreaktion (PCR). Mitteilungen aus dem Gebiet der Lebensmittel und Hygiene 88:515-524

19. Kuribara H, Matsuoka T, Takuba K, Futo S, Hirao T, Akiyama H, Goda Y, Toyoda M, Hino A (2002) Novel reference molecules for quantification of genetically modified maize and soy. J AOAC Int 85(5):1077-1089

20. Ma BL, Subedi K, Evenson L, Stewart G (2005) Evaluation of detection methods for genetically modified traits in genotypes resistant to European Corn Borer and Herbicides. J Environ Sci Health B 40:633-644
21. EC (2004) Commission Recommendation 787/2004 on technical guidance for sampling and detection of genetically modified organisms and material produced from genetically modified organisms as or in the context of Regulation (EC) 1830/2003. Off J Eur Communities L348:18-26

22. Lin H-Y, Chiang J-W, Shih DY-C (2001) Detection of genetically modified soybeans by PCR method and immunoassay kits. J Food Drug Anal 9(3):160-166 